\title{
The Low Management Level of Urban Waste and its Impact on Environment in the Lushnja Municipality
}

\author{
Aulent Guri \\ PhD in progress in Economy and Sustainable Development at UET University, Albania \\ E-mail: aulentguri@gmail.com \\ Prof. Sazan Guri \\ Prof.asc. Lecturer on Environmental Right in Tirana University, Albania \\ E-mail: sazanguri@gmail.com \\ Armend Aliu \\ PhD in progress in Finance, Lecturer at University of Prishtina - Kosovo \\ E-mail: armend_aliu@hotmail.com \\ Marianthi Guri \\ M.Sc. Environment Expert at Studio "G \& G group", Tirana, Albania \\ E-mail: mguri@gggroup-al.com \\ Jasmina Lumanaj \\ PhD in progress in Finance, Lecturer at Luigj Gurakuqi University, \\ Shkoder, Albania.__lumani@yahoo.com
}

Doi:10.5901/mjss.2013.v4n11p397

\section{Abstract}

The almost uncontrolled waste management activity in the condition of the biological factors degradation is bringing negative changes to the natural environment, such as in water, air and land, as well as in its physical chemical composition. The institutional apathy on the environmental protection field, that is being threatening to the environment, by no managing and no treating the urban waste, composing so the most unique case in the world, where the urban municipal waste threat with their three paradox, such as they are thrown out near the river systems or they are thrown out on loose deposits and they have been left in opened damps and burned into the air. Under this condition the paper treats and find out the ways how to accept an action local plan for a careful management and integrated treatment of them. The waste management is a national problem, as well. Legislation, public consideration and the other groups related with the growth tendency for the waste management problems has passed the geographical limits of a certain municipality. The engineering controlled landfill or sanitary one, today in the Albania is the dominating waste management option, irrespective they have not few problems related with technology and emissions. The papers deals with waste management in the way how to be collected or to promote discussion in Strategic Issues or provide and organize education in waste management, life cycle analysis, risk assessment, environmental impact assessment, EMAS, quality control procedures and cost benefit analysis., cost optimisation, separate collection, case studies, subsurface systems.

Keywords: waste management, landfill, risk assessment, environment impact, composing;

\section{Introduction}

Waste management strategies and technologies are currently under going rapid development. Albania is going through a crisis of the system related to the treatment of urban solid waste, which is a serious issue dealt by civil society and state institutions, in order to be solved as a challenge, but also as a reality in Albania. While the Albanian society is passing 
into trade economy, the production of solid waste in the country increased obviously. A series of import products entered for the first time into Albanian market. Raid increase of population, urbanism and expansion of activities revealed a nonefficient system for the actual administration of waste. The Albanian Government is involved in the process of full membership into the EU and in this context the Ministry of Environment has worked for the transposition of the main instruments of EU legislation into Albanian legislative instruments. The spinal column for the management of environmental infrastructure in the legislative field is based on Law No.10431, dated 9.6.2011 "For Environmental Protection", meanwhile that of urban waste administration according to Law No. 10 463, dated 22.9. 2011 "For the Integrated Waste Management".

\section{Literature review}

This chapter persists in various definitions from the lack of urban waste processing plants, incurring an uncontrolled distribution of waste, which cause the contamination of air, ground and water. The effects and concerns for such waste are related to soil, surface and underground waters, as well as air, smell (odors). The greatest problem in the administration of waste in Albania is not the lack of laws ${ }^{1}$, but of the following:

- lack of an institutional administration and technical plan, human resources, financial sources and investments in infrastructure;

- lack of experience/ tradition in the administration of this sector;

- lack of economic means used for waste administration;

- poor communication between local and central government on waste issue;

- poor collaboration between the community, business and managing enterprises on waste issue;

- lack of monitoring, the indicator and waste statistics;

- lack of networks in order to collect and process them, etc.

\section{The Target and Objectives of the Study}

The study aims to synthetize the management elements of municipality waste, which impacts on environment in the Lushnja municipality, by evaluating also the health risks for the residents in the surrounding areas, including concepts and methods for integrated waste treatments.

The objective of the study is to evaluate the level of environmental pollution (soils and surface waters and groundwater) to avoid health risks on Municipality Lushnja area from activity of the low management level of urban waste on the basis of the reason-consequence connection of the waste, with consequences on health, based on direct measurements of environmental elements and diagnosing of human health of the residents surrounding these areas and giving the relevant recommendations for the improvement of the situation.

The objectives of the study were realized based on the following:

- Selection of the main pollutant indicators which are present in the air, surface and underground waters in different situations and periods;

- Verification of contamination resources;

- Stipulation of pollution level in the ground, air and surface and underground waters;

\section{Research methodology}

The methodology of study is based on the realization of activities, such as:

* Observation on site, in a broad region, carrying out all the relevant pedological, geomorphological, hydrological, as well as ecological observations.

* Identification of issues which complete the assessment for environmental pollution;

* Localization of spots or areas of health risk;

* For the realization of objectives under the present study, the following were obtained:

- Sample extraction and photos of the territory under study;

- Meetings with local experts and area community;

- Testing of water and soil samples obtained;

${ }^{1}$ Albanian National Strategy of waste management, April 2010 
- Elaboration of results;

- Risk assessment: identification of resources, levels of exposure, localization and potential risks;

Argumentation based on the evaluation of:

- Collection and transportation of urban waste in the collection site;

- Spread of urban leachage waste waters in the waste field;

- Cleaning and disinfecting of the area around waste containers;

- Washing and disinfecting the waste containers;

- Maintenance of urban waste collection spots during the day;

Argumentation based on the evaluation of:

- Inventories of existing data;

- Basic information, in periodic publications on this area;

- Norms of discharges and emissions into the air and water discharges, according to

European and Albanian Legislation;

* Conformity with legal requirements, such as the quality of air, soil, surface waters and liquid flows.

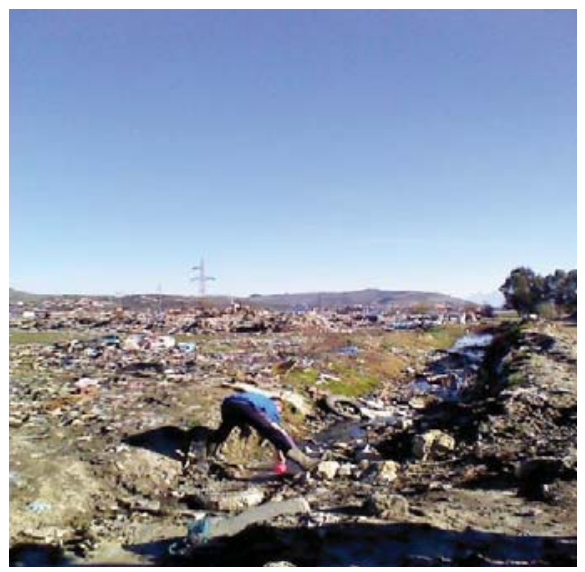

Foto 1. Water sample taken near Lushnja waste dump (@ A. Guri, March 2013)

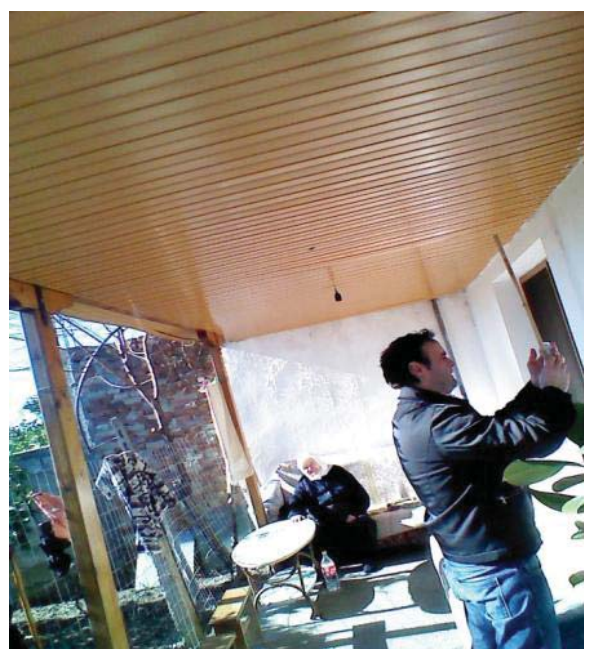

Foto 2. Air parameters measurement at the home yard near the waste dump (৫ A. Guri, March 2013) 


\section{Overview on the problem of the actual administration of urban waste in Lushnje}

Administration of Urban Waste in the Municipality of Lushnja has been made and continues to be made in a primitive way. They have been freely discharged in unsuitable areas and in agricultural lands, near irrigation channels, near residential areas, causing an uncontrolled spreading of them, which have influenced in the contamination of air, soil and water. Paradoxes of waste management in the city of Lushnja are the following:

- Collected in open storage places in nature;

- No processing or treatment is made;

- Places in friable deposits, cropland;

- Thrown near water systems (irrigation channels, waterworks);

- Burnt in free condition;

- Outside the conditions of medical control;

From approximative calculations (according to the report on the condition of environment in Albania, for the year 2010) the following assessments result for urban waste in this area:

- 20,120 ton/year, municipality waste for the Municipality of Lushnja.

Tab 1. The annual waste production amount in Lushnja Municipality

\begin{tabular}{|c|c|c|}
\hline Population & $\begin{array}{c}\text { Annual amount } \\
\text { ton/inhabitant }\end{array}$ & $\begin{array}{c}\text { Annual amount } \\
\text { Urban waste/ ton }\end{array}$ \\
\hline 29649 & 0.674 & 20000 \\
\hline
\end{tabular}

Source: Albanian Environmental Report, 2010

Tab 2. The characterization of mucipality in $\%$ of waste content in Lushnja, 2011

\begin{tabular}{|l|c|}
\hline Waste type & Concentration in \% \\
\hline Organic & 50.9 \\
\hline Wood & 1.3 \\
\hline Paper & 4.1 \\
\hline Card & 8.3 \\
\hline Plastic & 15 \\
\hline Glass & 2.2 \\
\hline Textile & 6.9 \\
\hline Ferrous metals & 0.2 \\
\hline Non ferrous metals & 0.4 \\
\hline Hospital waste & 0.1 \\
\hline Goma & 0.1 \\
\hline Inerts & 5.9 \\
\hline Sanitary waste & 4.5 \\
\hline Total & 100 \\
\hline
\end{tabular}

Source: Albanian National Waste Strategy, May 2010

Actually, the waste is collected according to a simple norm and it is deposited in open damp field. The place of discharge is located in an open field (Photo-3,4, March 2013, A. Guri), which is located in the south-west of Lushnja city, approximately $1 \mathrm{~km}$ from the city center. This place of deposit which is stipulated and which has not been surveyed is located on friable quaternary deposits, represented from suargils near the track of the railway and several housing buildings in a distance of $10 \mathrm{~m}$ from its boundaries. The actual area is the main spot for the collection of rubbish in Lushnje (Photos 3, 4, March 2013, A. Guri). The greatest amount of urban waste, as well as hospital waste are freely burnt for 20 years near a great water channel, which are then discharged into the waters of Shkumbin river, which, after being polluted from the lexiviati of urban waste is discharged into the sea. The presence of animals and poultries constitute a concern for the spread of infectious diseases. By means of complicated chemical and physical processes, dangerous substances penetrate into the food chain of people, plants and animals by communicating with depth, (friable 
sediments, water, etc.) due to high permeability of sandy particles, found in the layered formation of Quaternary, where they discharge, as well as from the lack of protection layer in the bottom section and lateral sides. There is also missing the drainage system for flows and filtrations from the waste amount (lexiviati). Water which drain from the discharge place, flow easily into the secondary water catchment and in Shkumbin river. Underground waters, which flow from the discharge place, are used for potable water and irrigation, in the bottom areas of the channel flow or Shkumbin River. The wells which are found in the bank of Shkumbin river, supply many villages of the area with potable water. The field collects water through several irrigation channels, which are located $10-100 \mathrm{~m}$ away from the waste. Drilled wells surrounding the region absorb water from a depth of about 5-8m underground. Due to the proximity of wells with channels and relatively shallow levels, filtration is huge. Smoke and bad odors are spreaded in a distance with a radius of up to $5 \mathrm{~km}$. From this place of discharge, methane gas is released and dust particles with heavy metal content, as well as other inorganic and organic contents, such as: dioxine, furans.

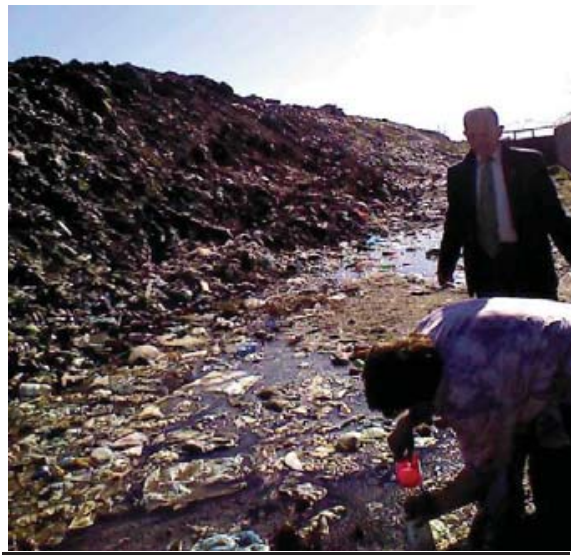

Foto 3. The contaminated surface water around the waste dump of Lushnja municipality (๑ A. Guri, March 2013)

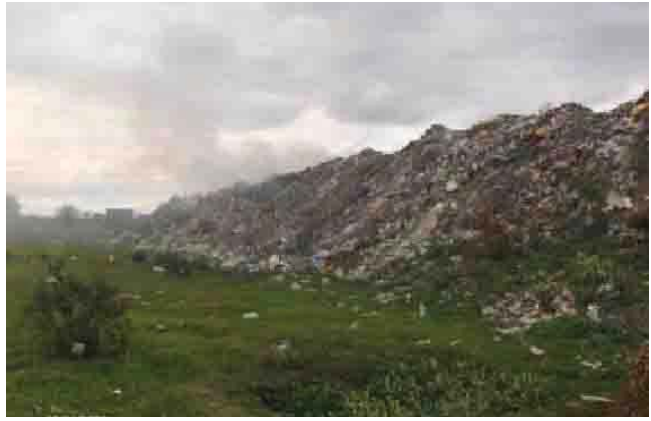

Foto 4. View from waste dump of Lushnje Municipality (৫ A. Guri, March 2013)

\section{Findings and discussion}

\subsection{Assessment of geological - engineering aspect}

The area is classified as an unfavorable area, because it has the following parameters:

- Heterogenous facia (clayey, alevroliths, sandy);

- Easy ability of communication between surface and underground waters;

- seismicity Mmax=6.0-6.9 or VIII grade;

- not very good geomorphological conditions; 
- liquefaction opportunity;

- near active tectonic area;

- mild average rocks;

- demographic impact;

- environmental and ecological impact;

\subsection{The data for the environment pollution}

In the concrete case, based on the test carried out, it results that dust particles PM10 are emitted in the air, which has resulted 5-6 times more polluted than the norm (table 3). We highlight that the measurements for dust content in the air have been made, not in the burning stage, but in normal and calm moments of waste, which naturally, at the moment of rubbish burning, we can say that the comparison is more high polluted. Nevertheless, from the measurement carried out, it results that matters in suspense is 4 times higher than the norm of the country or 6 times higher than the European norm.

Tab 3. Air indicator measurement in the house near Lushnja dump

\begin{tabular}{|c|c|c|}
\hline PM10 & Albanian limit & EU limit \\
\hline $236,56 \mathrm{ug} / \mathrm{m}^{3}$ & $70 \mathrm{ug} / \mathrm{m}^{3}$ & $50 \mathrm{ug} / \mathrm{m}^{3}$ \\
\hline
\end{tabular}

Source: Analyses Report no. 488, date 11.02.2013 from Environmental Monitoring Center - QMM, Tirana.

Measurements were carried out even in surface waters between the waste and the nearest housing building, and another sample for surface waters was taken from the channel near the waste, where waste water discharges from the waste dump. For these samples, we have the following results:

Tab 4. The physico-chemical analysis results of surface water near the urban waste dump of Lushnja city

\begin{tabular}{|c|c|c|c|c|}
\hline $\mathrm{Nr}$ & Elements & Results & $\begin{array}{c}\text { Albanian limit, Alb. } \\
\text { Gover. Deciss. 177 }\end{array}$ & EU limit \\
\hline 1 & $\mathrm{Ph}(\mathrm{pH})$ & 7,6 & $6-9$ & $6-9$ \\
\hline 2 & Suspended matter (mg/l) & 2125 & 35 & 25 \\
\hline 3 & $\mathrm{COD}(\mathrm{mg} / \mathrm{l})$ & 96 & 125 & 50 \\
\hline
\end{tabular}

Source: Analyses report Nr. 14, dt 28.01 2013, Institute of Public Health, Tirana

- $\quad$ ph is normal due to the mix of waste water and rain water.

- Matters in suspense is 61 times higher than the norm of the country or 85 times higher than European norm.

- Demand for chemical oxygen is as per Albanian norm, but 1.9 times higher than the European norm.

Tab 5. The analyses results of heavy metals concentrations in surface water near the dump waste in Lushnja city

\begin{tabular}{|c|c|c|c|c|}
\hline Elementet & Results & Albanian limit & EU limit & $\begin{array}{c}\text { The polluted amount in } \\
\text { higher then Albanian limit }\end{array}$ \\
\hline $\mathrm{Zn}(\mathrm{mg} / \mathrm{l})$ & 1.97 & $2,0 \mathrm{mg} / \mathrm{l}$ & 3 & $<$ \\
\hline $\mathrm{Cu}(\mathrm{mg} / \mathrm{l})$ & 0.173 & $<0.5 \mathrm{mg} / \mathrm{l}$ & $<0.5$ & $<$ \\
\hline $\mathrm{Co}(\mathrm{mg} / \mathrm{l})$ & 0.053 & $<0.5 \mathrm{mg} / \mathrm{l}$ & $<0.2$ & $<$ \\
\hline $\mathrm{Pb}(\mathrm{mg} / \mathrm{l})$ & 0.357 & $<0.5 \mathrm{mg} / \mathrm{l}$ & $<0.01$ & $<$ \\
\hline $\mathrm{Cd}(\mathrm{mg} / \mathrm{l})$ & 0.0034 & $0.02 \mathrm{mg} / \mathrm{l}$ & $<0.005$ & $<$ \\
\hline
\end{tabular}

Source: Analyses report Nr. 14, dt 01.02 2013, Nuclear Physics Institute, Tirana

From this test (Tab 5), it results that heavy metals in water are respectively in Albanian norm, but not in EU norm. In order to assess the impact on environment near the urban waste dump site in the city of Lushnja, measurements were made even in underground waters, which are used for drinking by the residents in the area, for which two samples were 
taken, one in the depth of $3 \mathrm{~m}$ from the surface and the other $10 \mathrm{~m}$ far from the dump site, hence in the nearest housing building and the other in the same depth, but $20 \mathrm{~m}$ far away from the dump site.

Tab 6. The bactereological analyses results of underground water ( $10 \mathrm{~m}$ from the urban waste dump) in Lushnja city

\begin{tabular}{|c|l|c|c|}
\hline $\mathrm{Nr}$ & Analytical index & Result & Albanian limit \\
\hline 1 & Coliforme totale & Too much & 0 \\
\hline 2 & E. Coli & 36 & 0 \\
\hline 3 & Streptococu phecal & 8 & 0 \\
\hline
\end{tabular}

Source: Analyses report Nr. 19, dt 01.02 2013, Institute of Public Health, Tirana

Tab 7. The physical-chemical analyses results of underground water (10m from the urban waste dump) in Lushnja city

\begin{tabular}{|c|l|c|c|c|c|}
\hline $\mathrm{Nr}$ & Chemical indicators & Result & $\begin{array}{c}\text { Albanian } \\
\text { limit }\end{array}$ & EU limit & $\begin{array}{c}\text { The polluted amount in } \\
\% \text { higher then Albanian limit }\end{array}$ \\
\hline 1 & Ph & 8,48 & $6.5-8.5$ & $6.5-8.5$ & \\
\hline 2 & Suspended matter $(\mathrm{mg} / \mathrm{l})$ & 531 & $\leq 30$ & $\leq 25$ & $1770 \%$ \\
\hline 3 & Ammoniac $(\mathrm{mg} / \mathrm{l})$ & 0,41 & $<0.05$ & $<0.01$ & $800 \%$ \\
\hline 4 & Nitrites $(\mathrm{mg} / \mathrm{l})$ & 2.39 & $<0.005$ & $<0.001$ & $47800 \%$ \\
\hline 5 & Nitrates $(\mathrm{mg} / \mathrm{l})$ & & $<15$ & $<0.5$ & \\
\hline 6 & Phosphates $(\mathrm{mg} / \mathrm{l})$ & 1,38 & $\leq 0.7 ;$ & $<0.2$ & $200 \%$ \\
\hline 7 & COD (mg/l) & 97,6 & $\leq 20$ & $\leq 20$ & $480 \%$ \\
\hline
\end{tabular}

Source: Analyses report Nr. 19, dt 08.02 2013, Institute of Public Health, Tirana

From this test (Table 7) for underground waters of the family well, shows the presence of ammoniac in water is a risky pollution of potable water ${ }^{2}$, as well as the content of nitrites in the value of $2.39 \mathrm{mg} / \mathrm{l}$, which are components that have a toxicity and their quantity in potable waters should not be higher than $0.005 \mathrm{mg} / \mathrm{l}$ according to Albanian standard. From this test for underground waters, it is observed the aggravation of chemical-physical parameters in it, the wells of residential houses near the dump site of urban waste, the hydraulic conductivity in $400 \%$, matters in suspense $13,333 \%$, ammoniac $1,800 \%$, as the result of lexiviaty impact of the urban waste dump site with 1,890\% above Albanian norm. If we compare them with the concentrations according to international standards of potable waters, then it is presented a rather pronounced pollution. From the comparison of values analyzed with Albanian norms and EU, it results that we deal with chemically and bacteriologically polluted water, and threatening for the health of residents 3 .

Tab 8. The physical-chemical analyses results of underground water ( $20 \mathrm{~m}$ from the urban waste dump) in Lushnja city

\begin{tabular}{|c|l|c|c|c|}
\hline $\mathbf{N r}$ & Chemical indicators & Result & Albanian limit & $\begin{array}{c}\text { The polluted amount in } \\
\% \text { higher then Albanian limit }\end{array}$ \\
\hline 3 & Ph & 7,03 & $6.5-8.5$ & \\
\hline 4 & Electrical conductivity (uS/cm) & 1600 & $\leq 400$ & $400 \%$ \\
\hline 5 & Calcium (mg/l) & 102 & 75 & $136 \%$ \\
\hline 6 & Suspended matter (mg/l) & 4 & $\leq 30 \mu \mathrm{g} / \mathrm{l}$ & $13333 \%$ \\
\hline 11 & Ammoniac (mg/l) & 0,903 & $\leq 0.05$ & $1800 \%$ \\
\hline 12 & Nitrites $(\mathrm{mg} / \mathrm{l})$ & 0 & $\leq 0.005$ & \\
\hline 13 & Nitrates (mg/l) & & $\leq 15$ & $200 \%$ \\
\hline 15 & Phosphates (mg/l) & 1,48 & $\leq 0.7$ & $160 \%$ \\
\hline 16 & Organical matter (mg/l) & 1,6 & 0 & $0 \%$ \\
\hline 18 & Suplhates (mg/l) & 250 & $250 \mathrm{mg} / \mathrm{l}$. & \\
\hline
\end{tabular}

Source: Analyses report Nr. 19, dt 08.02 2013, Institute of Public Health, Tirana 


\subsection{Evaluation of healthy riskness}

The risk is the relative probability of damage or injury, which is based on the natural toxicity of substances with content above the allowed norms and standards, which reach the people through physical contact, inhalation and the tract of food chain. Revealing the risk aims the identification and description in a comprehensive way of existing risks, really potential, which are produced from the existence of pollution in the water and in the air. Based on WHO-EEA, polluting substances in potable waters are selected as harmful priority substances in this area.

\subsection{Clinical characteristics of chronic intoxications}

The residents around the dump site are under the influence of pollution and negative effects in their health are sensible. Such effects have brought numerous and various organic and functional disorders, which have influenced in the decrease of ability to work and in many cases, have passed to medical control with aggravation of health condition. Pollutant components, being introduced into organism in small quantities and relatively for a long time, influencing chronic intoxications as the form which is more often encountered in the residents, who exercise their activity in this area. In the contigent of residents, where the medical check up has been carried out, the most frequent and severe complaints have been observed in the nervous and peripheric system, which belong to the disorders of the activity in this system with functional character. The clinical characteristics of such disorders are in the syndrome viscerale vegetative asthenia, with headache (Cefalea), often continued with not a strong intesity, aggravating sensation in the back area of the head, fatigue, loss of attention, lack of concentration, often sleepy condition, disorders in the mood, reduction of memory, sweating palms and soles. Cefalea has been present in $86 \%$ of cases. This condition is subject to age, years of living on this area, as well as profession. More pronounced it is at residents living near the dump site, as well as those who have more than 10 years of living in this area. Cefalea constitutes the periodic symptom of asthenis and has a different character from cefalea and other pathologic nature. It becomes more pronounced with the increase of physical and mental pressure, particularly during the night shift. In most cases, it is fixed the sense of general apathy, as a consequence, headache becomes more pronounced and continuous, reduction of attention and sight, both near and far away, photofobia and redness on eye. Such a syndrome constitutes a toxic encefalopathi or the so-called "Toxic Cerebroasthenia" and it is followed by organic alterations in the central nervous system. Poisoning gases which are produced from waste free burning also give sharp functional disorders in the liver, which is expressed with fat deposits, with hiperalbuminemia and hipergamaglobulinemia. Furthermore, in the cases which have been examined, it has been encountered reduction of glicogen in the liver, as well as the reduction of anti-toxic function, glikco-regulating of albumins. Sick residents complain for the dry sensation in the throat, as well as bitterness in the mouth, especially in the morning, thirsty for water at night, etc. Patients, who are presented to the aggravated health condition, have been admitted to hospital, where their treatment is done until improvement. This consists on $34.6 \%$ of controlled patients. Respiratory tract injuries are another concern at the resident of this area, where a series of complaints are: cough, runny and dry nose, toracoalgia, laeringite, etc. The diseases that predominate are: chronic bronchitis, chronic broncho pneumopatites associated with a considerable amount of respiratory, ventilatory, restrictive insufficiency, obstructive and mixed which make up $66 \%$ of the cases checked.

\section{Concluding remarks}

The most important results of the analyses for impact on environment from the dump site of urban waste are found in the air and surface and underground waters. The research presents situations of the low management level of urban waste and its impact on environment in the Lushnja municipality.

The assessment of environmental impact in the areas surrounding the dump site of urban waste was made by performing physical - chemical and bacteriological tests of environmental parameters, the stipulation of main pollutants and their origin.

Risk assessment was made by comparing the results obtained with Albanian and European standards. High values of chemical and bacteriological pollutants resulted.

Indicators of physical - chemical and bacteriological measured parameters express the increasing effect of pollution and concentration of pending substances, ammoniac, nitrites in the rate of $47,800 \%$.

The presence of ammoniac in water which is used by residents as potable water is a risky pollution, which threatens the health of these residents near the waste dump site. 
Nitrites are compositions, which have a high toxicity and their quantity in water shall not be greater than $0.005 \mathrm{mg} / \mathrm{l}$ nitrite according to Albanian norms.

Comparing the values of nitrite results with respectively $2.39 \mathrm{mg} / \mathrm{l}$ of Table 7 (physical - chemical test of underground waters at the family well $10 \mathrm{~m}$ far from the dump site of urban waste in the city of Lushnje) and 0 of table 8 (physical - chemical test of underground waters at the family well $20 \mathrm{~m}$ far away from the dump site of urban waste in the city of Lushnje) we observe that, going away from the contamination resource (waste dump site) the content of nitrites disappears.

Environmental risk assessment is made by comparing the results obtained with international standards.

\section{References}

WHO-EEA , Air and health, 1997

WHO, Air quality guidelines for Europe, Copenhagen 2000

WHO, Environmental health indicators for the WHO European region. Survey methods for environmental health assessment, 2002

WHO, Health-related air quality indicators and their application in health impact assessment in HEGIS, 1997

WHO, Reducing risks, promoting healthy life. The world health report 2002;

UNDP, Report of Alnanian environmental condition, 2001

UNDP, Common country assessment. ALBANIA, 2002

MSH dhe MM , Raport mbi gjendjen e mjedisit ne Shqiperi. Plani Nderkombetar i Veprimit, Tirane 2003

IFEN, Environmental performance indicators, Paris 1997

Deliu A., Kodra Q., informacion mbi cilesine e ajrit ne Shqiperi. Buletin i ISHP, nr.2/2001.

Corenssen I., Covello, Risk analysis: A guide to principles and methods for analyzing health and environmental risks, 1989.

Catrell C. Anthony, 2002, Oxford, UK. Malden Masachuttsets. Geographies of Health.

Draw B. Leksione te Gjeografise Mjeksore dhe Shendetit. Tr. 2004 